\title{
PENGARUH KUALITAS PRODUK DAN KEUNGGULAN BERSAING TERHADAP KEPUTUSAN PEMBELIAN DENGAN CITRA MEREK SEBAGAI VARIABEL INTERVENING
}

\author{
Netty Laura.S \\ Fakultas Ekonomi dan Bisnis Universitas 17 Agustus 1945 Jakarta \\ email:nettylaura919@yahoo.com \\ Siska Natalia Siringo Ringo \\ Fakultas Ekonomi dan Bisnis Universitas 17 Agustus 1945 Jakarta \\ email :siskanatalia54@yahoo.com
}

\begin{abstract}
ABSTRAK
Penelitian ini bertujuan untuk menjelaskan pengaruh kualitas produk dan keunggulan bersaing terhadap keputusan pembelian dengan citra merek sebagai variabel intervening di Universitas 17 Agustus 1945 Jakarta. Unit analisis dalam penelitian ini adalah mahasiswa pengguna sepeda motor Honda matik. Populasi dalam penelitian ini adalah mahasiswa pengguna sepeda motor Honda matik dengan jumlah 132 sampel dari 198 populasi. Metode pengambilan sampel dalam penelitian ini dilakukan dengan menggunakan purposive sampling, dimana pengambilan sampel secara sengaja berdasarkan persyaratan kriteria tertentu. Instrument analisis statistik melalui PLS.3 yang digunakan untuk menguji hipotesis. Hasil penelitian ini yakni kualitas produk berpengaruh positif signifikan terhadap citra merek di Universitas 17 Agustus 1945, keunggulan bersaing berpengaruh positif signifikan terhadap citra merek di Universitas 17 Agustus 1945, kualitas produk berpengaruh positif signifikan terhadap keputusan pembelian di Universitas 17 Agustus 1945, keunggulan bersaing berpengaruh positif signifikan terhadap keputusan pembelian di Universitas 17 Agustus 1945, citra merek berpengaruh positif signifikan terhadap keputusan pembelian di Universitas 17 Agustus 1945, kualitas produk berpengaruh tidak signifikan terhadap keputusan pembelian melalui citra merek di Universitas 17 Agustus 1945, dan keunggulan bersaing berpengaruh tidak signifikan terhadap keputusan pembelian melalui citra merek di Universitas 17 Agustus 1945. Implikasi penelitian ini PT. Astra Honda Motor perlu berinovasi terus menerus melalui kualitas produk sehingga mampu bersaing dengan perusahaan otomotif sepeda motor lainnya. Keunggulan bersaing yang diciptakan Honda inilah yang mampu menjadikan PT. Astra Honda Motor menjadi penguasa pasar industri otomotif sepeda motor.
\end{abstract}

Kata kunci:

Keputusan Pembelian, Citra Merek, Kualitas Produk dan Keunggulan Bersaing

\begin{abstract}
The purpose of this research is to explain the effect of product quality and competitive advantage on purchasing decisions with the brand's image as an intervening variable in the 17 August 1945 University Jakarta. Unit analysis in this study were students Honda automatic motorcycle users. The population in this study were students Honda automatic motorcycle users by the number of 132 samples from 198 population. The sampling method in this research is done by using purposive sampling, where sampling is deliberately based on the requirements some of criteria through PLS.3. Instrument statistical analysis used to test the hypothesis. The results of this study the quality of the product significant effect on brand image at the 17 August 1945 University, the competitive advantage of significant effect on brand image at the 17 August 1945 University, the product quality significant effect on purchasing decisions at the 17 August 1945 University, the competitive advantage of effect significantly influence purchasing decisions at the 17 August 1945 University, the brand image significant effect on purchasing decisions at the 17 August 1945 University, quality products not significant effect on purchasing decisions through brand image in the 17 August 1945 University, and the effect is not significant competitive advantage on purchasing decisions through brand image in the 17 August 1945 University. The implications of this research PT. Astra Honda Motor need to innovate continuously through product quality so as to compete with other motorcycles automotive companies. Honda created a competitive advantage that is able to make PT. Astra Honda Motor became the ruler of the motorcycle market automotive industry.
\end{abstract}

Keywords:

Purchasing Decisions, Brand Image, Quality Products and Competitive Advantage 


\section{PENDAHULUAN}

\subsection{Latar Belakang Masalah}

Pemasaran memiliki peranan penting di dalam suatu perusahaan, karena pemasaran adalah jantung kelangsungan hidup perusahaan dan menjadi ujung tombak keberhasilan suatu perusahaan (Kotler, 2010). Pemasaran merupakan kombinasi antara sebuah seni dan ilmu pengetahuan dalam rangka menghasilkan produk untuk memenuhi kebutuhan dan keinginan konsumen. Seperti yang diungkapkan oleh Kotler dan Keller (2012) bahwa pemasaran merupakan proses sosial yang dengan proses itu individu dan kelompok mendapatkan apa yang mereka butuhkan dan inginkan dengan menciptakan, menawarkan, dan secara bebas mempertukarkan produk dan jasa yang bernilai dengan pihak lain.

Industri otomotif dari tahun ke tahun semakin berkembang di Indonesia terutama sepeda motor Honda matic. Di kalangan mahasiswa Universitas 17 Agustus 1945 Jakarta (UTA'45). sepeda motor matic sangat diminati meskipun dilihat dari segi price (harga), sepeda motor Honda matic memiliki harga yang bersaing dan lebih tinggi dibandingkan dengan sepeda motor matic merek lainnya.

Tabel 1.

Data mahasiswa universitas 17 Agustus 1945 Jakarta yang menggunakan sepeda motor matic

\begin{tabular}{|c|l|l|}
\hline No & $\begin{array}{l}\text { Merek Sepeda Motor } \\
\text { Yang Digunakan }\end{array}$ & Jumlah \\
\hline 1 & Honda Matic & 198 Unit \\
\hline 2 & Yamaha Matic & 104 Unit \\
\hline 3 & $\begin{array}{l}\text { Suzuki Matic } \\
\text { Pumlah Keseluruhan } \\
\text { Motor Matic Sepeda }\end{array}$ & 315 Unit \\
\hline
\end{tabular}

Sumber : Data Olahan, 2016

Berdasarkan data penggunaan sepeda motor matic pada mahasiswa Universitas 17 Agustus 1945 Jakarta (UTA’45) diatas, terlihat jelas bahwa dari total mahasiswa Universitas 17 Agustus 1945 Jakarta (UTA'45) sebanyak 1.812 mahasiswa, terdapat 315 mahasiswa yang rutin menggunakan sepeda motor matic sebagai alat transportasi mahasiswa menuju ke Universitas 17 Agustus 1945 Jakarta. Berdasarkan survei yang telah dilakukan, terlihat bahwa mahasiswa lebih tertarik untuk menggunakan sepeda motor Honda matic dibandingkan sepeda motor Yamaha matic maupun sepeda motor Suzuki matic. Terdapat 198 mahasiswa yang menggunakan sepeda motor Honda matic, mahasiswa pengguna 
sepeda motor Yamaha matic berada diurutan kedua dengan jumlah 104 mahasiswa dan urutan terakhir adalah pengguna sepeda motor Suzuki matic sebanyak 13 mahasiswa.

Berdasarkan latar belakang di atas menjadi ketertarikan penulis untuk melakukan penelitian skripsi dengan judul "Pengaruh Kualitas Produk dan Keunggulan Bersaing terhadap Keputusan Pembelian dengan Citra Merek sebagai Variabel Intervening."

\subsection{Perumusan Masalah}

Berikut ini adalah perumusan masalah yang terjadi dalam penelitian ini :

a. Apakah kualitas produk berpengaruh positif signifikan terhadap citra merek?

b. Apakah keunggulan bersaing berpengaruh positif signifikan terhadap citra merek?

c. Apakah kualitas produk berpengaruh positif signifikan terhadap keputusan pembelian?

d. Apakah keunggulan bersaing berpengaruh positif signifikan terhadap keputusan pembelian?

e. Apakah citra merek berpengaruh positif signifikan terhadap keputusan pembelian? f. Apakah kualitas produk berpengaruh positif signifikan terhadap keputusan pembelian melalui citra merek?

g. Apakah keunggulan bersaing berpengaruh positif signifikan terhadap keputusan pembelian melalui citra merek?

\section{Tinjauan Teori dan Pengembangan Hipotesis}

\section{Consumer Decision Model Theory}

Grand Theory yang dilakukan dalam penelitian ini adalah Teori Keputusan Pembelian Konsumen (Consumer Decision Model Theory). Teori Keputusan Pembelian Konsumen (Consumer Decision Model Theory) adalah suatu tahapan dimana pembeli menetapkan pilihannya, memutuskan untuk membeli produk tersebut serta mengkonsumsinya (Suharno, 2010). Pengambilan keputusan konsumen melakukan pembelian suatu produk diawali dengan adanya kesadaran atas kebutuhan dan keinginan konsumen itu sendiri. Selanjutnya konsumen akan mencari informasi mengenai keberadaan produk yang diinginkannya tersebut. Proses pencarian informasi produk tersebut dilakukan dengan mengumpulkan semua informasi yang berhubungan dengan produk yang diinginkan 
dari berbagai sumber, dan selanjutnya melakukan seleksi atas alternatif - alternatif yang tersedia.

Model keputusan pembelian konsumen memiliki tiga peranan penting. Tiga hal penting dalam memahami model keputusan pembelian konsumen yaitu sebagai berikut (Sunyoto, 2013:91) :

a. Dengan model yang ada, pandangan terhadap perilaku konsumen dapat dilihat dalam perspektif yang terintegrasi.

b. Model keputusan pembelian konsumen dapat dijadikan sebagai landasan atau dasar dalam mengembangkan strategi pemasaran efektif.

c. Model keputusan pembelian konsumen dijadikan sebagai dasar untuk segmentasi dan positioning.

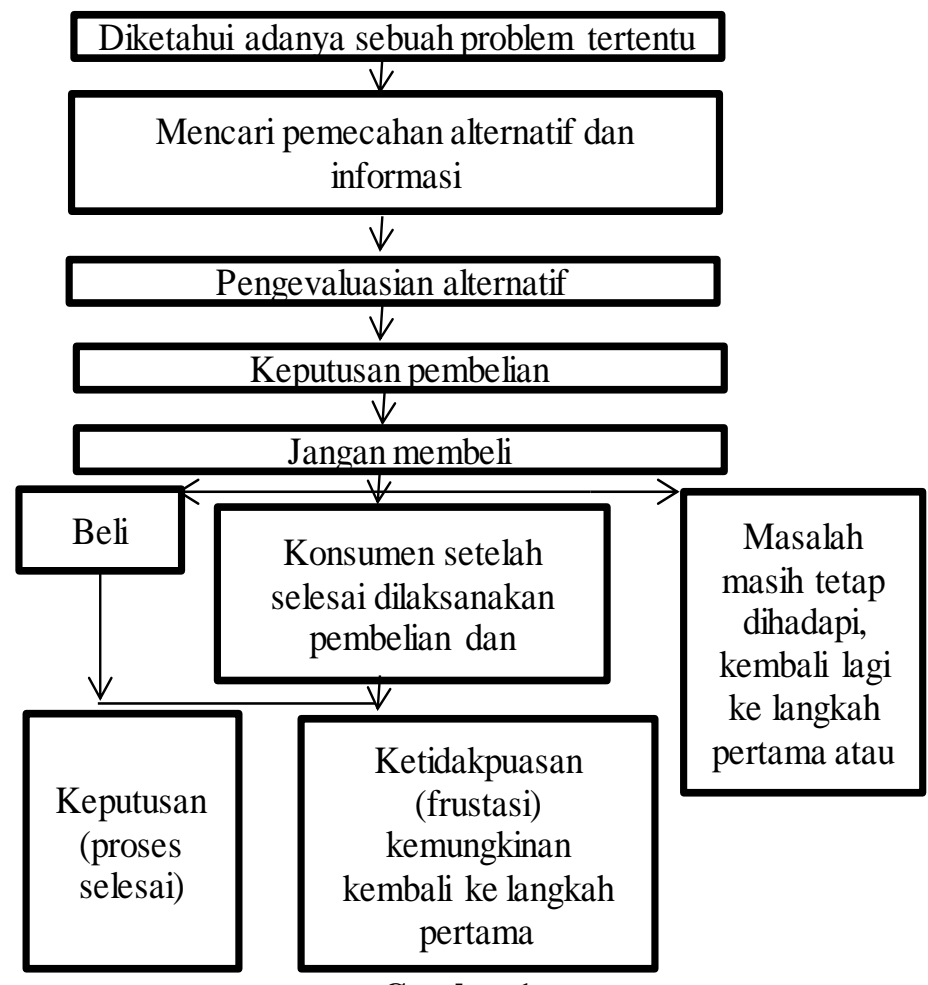

Gambar 1.

Proses pengambilan keputusan konsumen 
Consumer Decision Model dalam penelitian ini menjadi hal yang penting karena dipergunakan untuk menjelaskan pengambilan keputusan pembelian, baik dengan karakteristik sederhana maupun kompleks. Permasalahan pembelian sederhana hanya bergantung pada pencarian internal memori atau pengalaman terdahulu, sedangkan untuk permasalahan konsumsi yang kompleks memerlukan pencarian informasi secara eksternal yang lebih ekstensif.

\section{Keputusan Pembelian}

Keputusan pembelian merupakan keputusan untuk meneruskan pembelian atau tidak meneruskan pembelian suatu produk (Kotler dan Keller, 2012), Sumarwan (2008) sebagai pemilihan suatu tindakan dari dua atau lebih pilihan alternatif. Keputusan pembelian dapat diartikan sebagai suatu proses penilaian dan pemilihan dari berbagai alternatif sesuai dengan kepentingan - kepentingan tertentu yang dianggap paling menguntungkan dengan menetapkan suatu pilihan (Priyanto dkk, 2014). Salah satu cara untuk mempengaruhi keputusan konsumen dalam membeli produk dengan menggunakan pemasaran yang menarik dimana keputusan pembelian produk menjadi sesuatu yang sangat didambakan perusahaan terutama pihak pemasar (Puspita dkk, 2016). Setiap perusahaan akan berupaya menjalankan berbagai strategi pemasaran agar konsumen memutuskan membeli produk yang dipasarkan tersebut. Ada beberapa peranan konsumen dalam proses pengambilan keputusan pembelian. Terdapat beberapa faktor pendorong yang sangat kuat yang dipengaruhi oleh sejumlah orang yang memiliki keterlibatan dalam pengambilan keputusan pembelian (Swastha dan Handoko, 2011). Beberapa orang yang memiliki keterlibatan dalam keputusan pembelian antara lain :

a. Initiator adalah orang yang berinisiatif mengusulkan untuk membeli produk tertentu dan merupakan orang yang pertama kali menyadari adanya kebutuhan yang belum terpenuhi.

b. Influencer adalah orang yang sering memberikan nasihat atau pendapatnya untuk mempengaruhi decider dalam memutuskan membeli suatu produk.

c. Decider adalah orang yang berperan mengambil keputusan dalam menentukan apakah produk jadi dibeli, produk apa yang akan dibeli, bagaimana cara membeli produk 
tersebut, dan dimana produk itu dapat dibeli.

d. Buyer adalah orang yang berperan melakukan pembelian aktual.

e. User adalah orang yang menggunakan atau mengkonsumsi produk yang telah dibeli.

\section{Indikator Keputusan Pembelian}

Indikator keputusan pembelian menurut Kotler dan Keller (2012:171) adalah sebagai berikut

a. Pilihan produk, dengan cara memilih produk berdasarkan kegunaan

b. Pilihan penyalur, dengan cara memilih produk atau jasa berdasarkan penyalur

c. Waktu pembelian, dengan cara memutuskan pembelian berdasarkan waktu

d. Jumlah pembelian, dengan cara memutuskan membeli berdasarkan jumlah pembelian sesuai dengan kebutuhan

e. Metode pembayaran, dengan cara memutuskan membeli berdasarkan metode pembayaran yang disediakan Indikator dari keputusan pembelian menurut Tambunan dan Widiyanto (2012) adalah sebagai berikut :
a. Menetapkan pilihan terhadap produk
b. Rekomendasi kepada orang lain
c. Melakukan pembelian ulang
d. Keyakinan untuk membeli

\section{Kualitas Produk}

Salah satu faktor pertimbangan konsumen untuk membeli produk yang diinginkan adalah kualitas dari produk yang akan dibeli tersebut. Perusahaan harus dapat memberikan kualitas yang sesuai dengan kebutuhan dan keinginan konsumen dengan memperhatikan standar - standar kualitas pasar yang ada (Puspita dkk, 2016). Kualitas produk adalah kemampuan produk dalam meragakan fungsinya (Ginting, 2012:96), kemampuan suatu produk dalam melaksanakan fungsinya, meliputi keandalan produk, daya tahan, kemudahan dalam mengoperasikan dan perbaikan, ketepatan, serta atribut bernilai lainnya (Kotler dan Amstrong, 2012:283). Berdasarkan definisi di atas dapat ditarik kesimpulan bahwa kualitas produk merupakan kemampuan suatu produk dalam rangka memenuhi kebutuhan dan keinginan konsumen sesuai dengan standar kualitas yang berlaku.

Konsumen akan cenderung melakukan pembelian ulang apabila kualitas produk yang 
dihasilkan baik, sedangkan konsumen akan mengalihkan pembeliannya pada produk sejenis lainnya apabila kualitas produk tidak sesuai dengan apa yang diharapkan oleh konsumen. Kecocokan penggunaan suatu produk apabila produk tersebut tidak mudah rusak, daya tahan penggunaannya lama, produk yang digunakan mampu meningkatkan status konsumen yang memakainya, serta adanya jaminan kualitas produk. Menurut Kotler dan Amstrong (2006:299) kecocokan penggunaan produk memiliki dua aspek utama yaitu :

a. Produk memiliki ciri - ciri khusus yang mampu memenuhi permintaan pelanggan.

Produk yang berkualitas tinggi memiliki ciri - ciri produk khusus atau berbeda dari produk pesaing sejenis lainnya, sehingga mampu memenuhi harapan pelanggan serta memuaskan pelanggan.

b. Produk bebas dari kelemahan.

Produk dikatakan berkualitas tinggi apabila dalam produk tidak terdapat kelemahan dan cacat sedikit pun. Perusahaan harus mampu menciptakan produk berkualitas tinggi dengan segala spesifikasinya, sehingga dapat menarik minat konsumen untuk melakukan pembelian produk tersebut.

Menurut Kotler dan Arsmtrong (2007:338) produk terdiri dari tiga komponen utama yaitu sebagai berikut :

a. Produk inti (core product).

Merupakan alasan seorang pelanggan untuk membeli suatu produk atau manfaat utama dari suatu produk yang benar - benar dicari oleh pelanggan.

b. Produk aktual (actual product). Merupakan atribut utama yang dimiliki produk dalam mengkomunikasikan manfaat produk tersebut kepada konsumen. Produk aktual (actual product) minimal harus memiliki lima sifat yaitu kualitas, fitur, desain, merek dan kemasan.

c. Produk tambahan (augmented product).

Merupakan manfaat atau service tambahan yang diperoleh pelanggan melalui produk tersebut dalam rangka memenuhi kebutuhan 
pelanggan, seperti pembayaran dan pengiriman, pelayanan purna jual, garansi, pemasangan dan lain - lain.

\section{Indikator Kualitas Produk}

Indikator kualitas produk menurut

Ghanimata dan Kamal (2012) antara lain :

a. Keawetan produk

b. Bahan baku yang teruji berkualitas (kuat)

c. Didesain dengan cara yang aman

d. Mampu membuat dalam jumlah volume yang banyak

Indikator kualitas produk menurut Yusup (2011) antara lain meliputi :

a. Keiritan bahan bakar

b. Produk tidak mudah rusak dan memiliki umur ekonomis yang lama

c. Daya tahan mesin yang tangguh

d. Penampilan produk yang menarik

\section{Keunggulan Bersaing}

Kondisi lingkungan bisnis pada saat ini yang sangat kompetitif mendorong perusahaan untuk mampu membedakan produk yang dihasilkan di dalam persaingan untuk mendapatkan keunggulan bersaing. Produk yang dihasilkan harus memiliki karakteristik khusus dalam merebut hati konsumen sehingga menjadi produk yang spesial di hati konsumen. Keunggulan bersaing hanya dapat dicapai dengan mengembangkan produk dengan sangat spesial dan lebih menguntungkan dibandingkan dengan para pesaing (Sunyoto, 2015).

Keunggulan bersaing adalah keunggulan di atas pesaing baik melalui harga yang lebih rendah atau dengan menyediakan lebih banyak manfaat yang mendukung penetapan harga lebih mahal, sehingga dapat memberikan nilai lebih kepada konsumen (Kotler dan Amstrong, 2005:322), kemampuan, skill, asset, kapabilitas dan lainnya yang memampukan perusahaan bersaing secara efektif di dalam industri (Sampurno, 2010). Menurut Purba (2011) keungggulan bersaing pada dasarnya tumbuh dari nilai atau manfaat yang diciptakan oleh perusahaan bagi para pembelinya yang lebih dari biaya yang harus dikeluarkan oleh perusahaan untuk menciptakannya. Terdapat tiga pilihan strategi generik yang dapat dilakukan perusahaan untuk memperoleh keunggulan bersaing (Jatmiko, 2004) antara lain :

a. Strategi kepemimpinan biaya rendah (the cost of leadership). 
Strategi kepemimpinan biaya rendah

(the cost of leadership) adalah

rangkaian kegiatan untuk

memproduksi dan menawarkan barang

atau jasa dengan biaya yang paling

rendah terhadap para pesaing dengan

ciri - ciri produk atau jasa yang dapat

diterima oleh para pelanggan.

Perusahaan yang memiliki keunggulan

dalam hal biaya secara keseluruhan

dapat memanfaatkan keunggulan ini

untuk menetapkan harga rendah atau

mengambil marjin laba yang lebih

tinggi. Perusahaan yang memiliki

kemampuan untuk membuat produk atau jasa dengan biaya yang lebih rendah dan menjualnya dengan harga yang mampu memberikan laba yang lebih besar dibandingkan pesaing lainnya, maka perusahaan berada pada posisi yang lebih baik antara lain :

a) Dalam situasi persaingan perang harga memungkinkan perusahaan mampu bertahan dan menghalangi para pesaing lainnya dengan biaya yang lebih tinggi (untuk mampu bertahan dari perang harga, menikmati laba yang tinggi, dan menyerang pesaing dari sudut harga).

b) Laba yang lebih tinggi dapat di reinvestasikan untuk memperbaiki kualitas produk maupun jasa.

c) Menghalangi masuknya kompetitor baru.

d) Kenaikan harga bahan baku dari suplier dapat diredam dengan keunggulan biaya yang dimiliki perusahaan.

b. Strategi differensiasi.

Strategi differensiasi adalah rangkaian tindakan integratif yang dirancang perusahaan untuk memproduksi dan menawarkan barang atau jasa yang dianggap berbeda dalam hal - hal penting dan unik oleh para pelanggan.

c. Strategi fokus.

Strategi fokus adalah rangkaian tindakan integratif yang dirancang oleh perusahaan untuk memproduksi dan menawarkan barang atau jasa untuk melayani pasar wilayah geografi tertentu atau kebutuhan segmen persaingan tertentu. 
Indikator Keunggulan Bersaing

Indikator keunggulan bersaing menurut Shintia (2012) antara lain :

a. Keunggulan biaya meliputi :

a) Bahan baku yang mudah didapat dan harga yang murah

b) Efisiensi dalam produksi

c) Pemasaran dan distribusi yang hemat dan lancar

b. Keunggulan diferensiasi meliputi :

a) Bentuk corak / motif produk

b) Keragaman desain produk

c) Keragaman ukuran produk

Menurut Thatte (2007) indikator keunggulan bersaing antara lain meliputi :

a. Harga produk atau jasa yang bersaing

b. Kualitas pelayanan yang diberikan

c. Delivery Dependability

d. Inovasi produk yang diproduksi

e. Time to market (waktu pembelian)

\section{Citra Merek}

Citra merek adalah "perception and beliefs held by consumer as reflected in the associations held in consumer memory". Artinya konsumen akan mengikuti atau menganut persepsi dan kepercayaan berdasarkan pengalaman yang telah dirasakan dan telah terangkum di dalam ingatan konsumen (Kotler dan Keller, 2012:263-264), pandangan mengenai merek berupa refleksi memori konsumen akan asosiasinya pada merek tersebut (Ferrinadewi, 2008:165).

Merek dibagi menjadi beberapa tipe menurut Whitwell, et al dalam Tjiptono (2008:539) antara lain :

a. Atribute brand, yaitu citra merek yang mampu mengkomunikasikan keyakinan atau kepercayaan terhadap atribut fungsional produk.

b. Aspirational brand, yaitu merek yang tidak banyak menyangkut produknya tetapi justru lebih banyak berkaitan dengan gaya hidup yang didambakan oleh konsumen itu sendiri. Merek disini mampu menyampaikan citra konsumen atau tipe orang yang membeli merek bersangkutan.

c. Experience brand, yaitu tipe merek ini memiliki citra yang melebihi aspirasi dan lebih berkenan dengan kesamaan filosofi antara konsumen individual itu sendiri dan merek produk tersebut. 


\section{Indikator Citra Merek}

Indikator - indikator yang membentuk citra merek menurut (Edi, 2013) antara lain :
a. Mudah dikenali
b. Reputasi yang baik
c. Selalu diingat

Citra merek memiliki beberapa indikator menurut Tjiptono (2008:25) antara lain meliputi :
a. Kemasan produk, logo dan warna
b. Manfaat fungsional atau keawetan
c. Harga produk
d. Kualitas produk yang dimiliki
e. Gaya hidup
f. Perasaan konsumen
g. Status sosial seseorang atau
konsumen

\section{Hubungan Antar Variabel}

\section{Pengaruh Kualitas Produk terhadap Citra}

\section{Merek}

Kualitas adalah ciri dan sifat suatu produk atau pelayanan yang berpengaruh untuk memuaskan kebutuhan konsumen baik yang dinyatakan maupun yang tersirat (Kotler, 2012:49). Kualitas produk menjadi hal yang sangat penting karena itu menyangkut kepercayaan konsumen terhadap produk dan perusahaan itu sendiri sebagai produsen.
Kualitas produk berkaitan erat dengan citra merek, karena kualitas yang baik akan melahirkan citra yang positif dibenak konsumen sehingga konsumen menjadi percaya terhadap produk tersebut (Anis dkk, 2015).

Apabila kualitas produk baik di mata konsumen, maka secara otomatis terbentuk citra merek yang positif di mata konsumen. Berdasarkan hasil penelitian terdahulu mengemukakan bahwa kualitas produk berpengaruh positif signifikan terhadap citra merek (Noerchoidah, 2013; Anis dkk, 2015; Yusmawan et al, 2014). Berdasarkan penelitian terdahulu maka hipotesis yang dirumuskan adalah :

$\mathrm{H}_{1}$ : kualitas produk berpengaruh positif signifikan terhadap citra merek.

Pengaruh Keunggulan Bersaing terhadap

\section{Citra Merek}

Keunggulan bersaing dapat mempengaruhi citra merek produk maupun perusahaan. Keunggulan yang dimiliki produk mampu mendorong citra merek atas produk tersebut. Keunggulan bersaing yang dimiliki perusahaan berkaitan erat dengan strategi pemasaran yang dilakukan. Strategi pemasaran yang efektif selalu diawali dengan informasi 
yang akurat mengenai siapa saja konsumen perusahaan. Dalam rangka menarik minat beli konsumen, apabila pemasar dapat menciptakan merek yang bisa menjadi pengikat antara pelanggan dan perusahaan, maka strategi pemasaran berjalan dengan efektif. Kepercayaan konsumen pada citra merek dapat diperoleh apabila pemasar dapat menciptakan serta mempertahankan hubungan emosional yang positif dengan konsumen, yang dibangun secara konsisten dalam jangka waktu yang cukup lama. Hal ini juga dikemukakan Purba (2011) bahwa perusahaan harus memiliki strategi bersaing yang berbeda dengan yang dilakukan oleh perusahaan saingan sehingga mampu menciptakan kepercayaan konsumen terhadap produk melalui hubungan emosional yang positif.

Berdasarkan hasil penelitian terdahulu mengemukakan bahwa keunggulan bersaing berpengaruh positif signifikan terhadap citra merek (Ratnawati, 2013; Lubis, 2012; Erlangga dan Sisilia, 2014). Berdasarkan penelitian terdahulu maka hipotesis yang dirumuskan adalah :

$\mathrm{H}_{2}$ : keunggulan bersaing berpengaruh positif signifikan terhadap citra merek.

\section{Pengaruh Kualitas Produk terhadap}

\section{Keputusan Pembelian}

Kualitas produk berkaitan erat dengan keputusan pembelian, dimana kualitas produk menjadi salah satu aspek yang dipertimbangkan konsumen dalam memutuskan pembelian. Semakin baik kualitas produk yang dihasilkan perusahaan maka akan memberikan kesempatan kepada konsumen untuk memutuskan pembelian produk (Kotler dan Amstrong, 2008). Kualitas produk yang baik berujung pada kepuasan konsumen dan akan membuat konsumen menjadi loyal terhadap produk yang dipasarkan tersebut. Perusahaan harus memperhatikan standar standar kualitas pasar yang ada sehingga perusahaan mampu menyediakan dan memberikan kualitas produk sesuai dengan kebutuhan dan keinginan konsumen.

Berdasarkan hasil penelitian terdahulu mengemukakan bahwa kualitas produk berpengaruh positif signifikan terhadap keputusan pembelian (Purwati dkk, 2012; Puspita dkk, 2016; Hasan, 2015). Berdasarkan peneliti terdahulu maka hipotesis yang dirumuskan adalah:

$\mathrm{H}_{3}$ : kualitas produk berpengaruh positif signifikan terhadap keputusan pembelian. 
Pengaruh Keunggulan Bersaing terhadap

Keputusan Pembelian

Keunggulan bersaing merupakan kemampuan, skill, asset, kapabilitas dan lainnya yang memampukan perusahaan bersaing secara efektif di dalam industri (Sampurno, 2010). Keunggulan bersaing tumbuh dari nilai yang diciptakan perusahaan bagi para konsumennya dengan cara perusahaan mengeluarkan biaya lebih untuk menciptakan produk tersebut. Kekuatan berupa keunggulan bersaing yang dimiliki oleh suatu produk dapat membentuk persepsi konsumen mengenai produk dan mendorong minat beli konsumen terhadap produk tersebut.

Berdasarkan hasil penelitian terdahulu mengemukakan bahwa keunggulan bersaing berpengaruh positif signifikan terhadap keputusan pembelian (Diyah, 2013; Saputra dkk, 2015; Mahmud, 2014). Berdasarkan peneliti terdahulu maka hipotesis yang dirumuskan adalah:

$\mathrm{H}_{4}$ : keunggulan bersaing berpengaruh positif signifikan terhadap keputusan pembelian.
Pengaruh Citra Merek terhadap Keputusan

\section{Pembelian}

Merek menjadi salah satu pertimbangan utama yang ada di benak konsumen sebelum memutuskan melakukan pembelian suatu produk. Citra merek mampu mempengaruhi perilaku konsumen dan kepercayaan konsumen terhadap produk yang ditawarkan sehingga mampu mempengaruhi keputusan pembelian konsumen. Oleh sebab itu penting bagi perusahaan untuk menjamin citra merek produk. Citra merek yang positif akan mudah diingat oleh konsumen dan mempermudah pengambilan keputusan dalam melakukan pembelian. Semakin baik citra produk di mata konsumen, maka semakin meningkat pula penjualan produk tersebut. Hal ini juga dikemukakan Darmayanti dan Jatra (2016) bahwa semakin baik citra suatu merek, maka semakin tinggi keputusan konsumen dalam memilih atau memutuskan pembeliannya pada suatu produk.

Berdasarkan hasil penelitian terdahulu mengemukakan bahwa citra merek berpengaruh positif signifikan terhadap keputusan pembelian (Darmayanti dan Jatra, 2016; Ristiawan dan Farida, 2015; Listyawati, 
2014). Berdasarkan peneliti terdahulu maka hipotesis yang dirumuskan adalah:

$\mathrm{H}_{5}$ : citra merek berpengaruh positif signifikan terhadap keputusan pembelian.

\section{Pengaruh Kualitas Produk terhadap} Keputusan Pembelian melalui Citra Merek

Kualitas produk menjadi suatu hal penting yang dipertimbangkan konsumen sebelum konsumen memutuskan membeli suatu produk. Konsumen cenderung akan akan melakukan pembelian ulang apabila kualitas produk yang dihasilkan baik, sedangkan konsumen akan beralih ke produk lain yang sejenis apabila kualitas produk tidak sesuai dengan yang diharapkan konsumen. Apabila suatu produk diyakini oleh konsumen memiliki kualitas produk yang baik dan dapat memenuhi kebutuhan dan keinginannya serta memiliki citra merek yang positif, maka secara tidak langsung mampu mendorong keputusan pembelian konsumen akan produk yang ditawarkan. Begitu juga sebaliknya apabila citra merek produk yang ditawarkan negatif dimata konsumen dan produk berkualitas rendah, maka keputusan pembelian konsumen terhadap produk yang ditawarkan berkurang, bahkan konsumen bisa juga tidak memutuskan membeli produk tersebut. Konsumen senantiasa menilai kinerja produk yang dapat dilihat dari kemampuan produk dalam menciptakan kualitas produk sehingga mampu menarik minat konsumen untuk melakukan pembelian produk, dan dengan kualitas produk yang memuaskan konsumen itulah terbentuk citra merek yang positif dibenak konsumen. Keunggulan kualitas yang dimiliki suatu produk akan mempengaruhi persepsi dan keyakinan konsumen untuk membeli. Dengan kualitas yang unggul, maka citra merek yang sudah dibangun dan positif akan menambah kualitas produk dimata konsumen, dan akan berpengaruh terhadap keputusan pembelian produk yang akan dilakukan oleh konsumen.

Berdasarkan hasil penelitian terdahulu mengemukakan bahwa kualitas produk berpengaruh positif signifikan terhadap keputusan pembelian melalui citra merek (Wahid, 2014). Peneliti terdahulu juga mengatakan kualitas produk memiliki pengaruh positif signifikan terhadap keputusan pembelian (Saidani dkk, 2013). Peneliti terdahulu mengatakan kualitas produk memiliki pengaruh positif signifikan terhadap citra merek (Gu, 2013). Peneliti terdahulu mengatakan citra merek berpengaruh positif signifikan terhadap keputusan pembelian 
(Listyawati, 2014). Berdasarkan peneliti terdahulu maka hipotesis yang dirumuskan adalah:

$\mathrm{H}_{6}$ : kualitas produk berpengaruh positif signifikan terhadap keputusan pembelian melalui citra merek.

\section{Pengaruh Keunggulan Bersaing terhadap}

Keputusan Pembelian melalui Citra Merek

Keunggulan bersaing adalah

kemampuan, asset, skill, kapabilitas dan lainnya yang memampukan perusahaan untuk bersaing secara efektif di dalam industri (Sampurno, 2010:154). Keunggulan bersaing melalui bauran pemasaran (marketing mix) dapat mempengaruhi konsumen untuk memutuskan membeli suatu produk. Keunggulan yang dimiliki produk tersebut dapat mempengaruhi persepsi konsumen terhadap produk dan membentuk citra merek yang positif dibenak konsumen. Setiap Perusahaan akan bersaing dengan menciptakan produk yang berkualitas tinggi dan memberikan pelayanan terbaik (service excellent) terhadap konsumen sehingga konsumen akan merasa puas dan memutuskan untuk melakukan pembelian ulang terhadap produk tersebut. Dengan keunggulan produk yang berbeda dibandingkan produk sejenis lainnya, maka citra merek yang positif tersebut akan menciptakan keunggulan bersaing produk dimata konsumen dan akan mempengaruhi keputusan pembelian konsumen.

Berdasarkan hasil penelitian terdahulu mengemukakan bahwa keunggulan bersaing berpengaruh positif signifikan terhadap keputusan pembelian (Diyah dkk, 2013). Peneliti terdahulu juga mengatakan keunggulan bersaing memiliki pengaruh positif signifikan terhadap citra merek (Ratnawati, 2013). Peneliti terdahulu juga mengatakan citra merek memiliki pengaruh positif signifikan terhadap keputusan pembelian (Sari, 2013). Berdasarkan peneliti terdahulu maka hipotesis yang dirumuskan adalah:

$\mathrm{H}_{7}$ : keunggulan bersaing berpengaruh positif signifikan terhadap keputusan pembelian melalui citra merek.

\section{Kerangka Pemikiran}

Kerangka pemikiran adalah dasar pemikiran yang disintesiskan dari fakta -fakta dan observasi. Untuk memudahkan pemahaman mengenai keseluruhan rangkaian penelitian ini, maka disusunlah kerangka penelitian sebagai berikut 


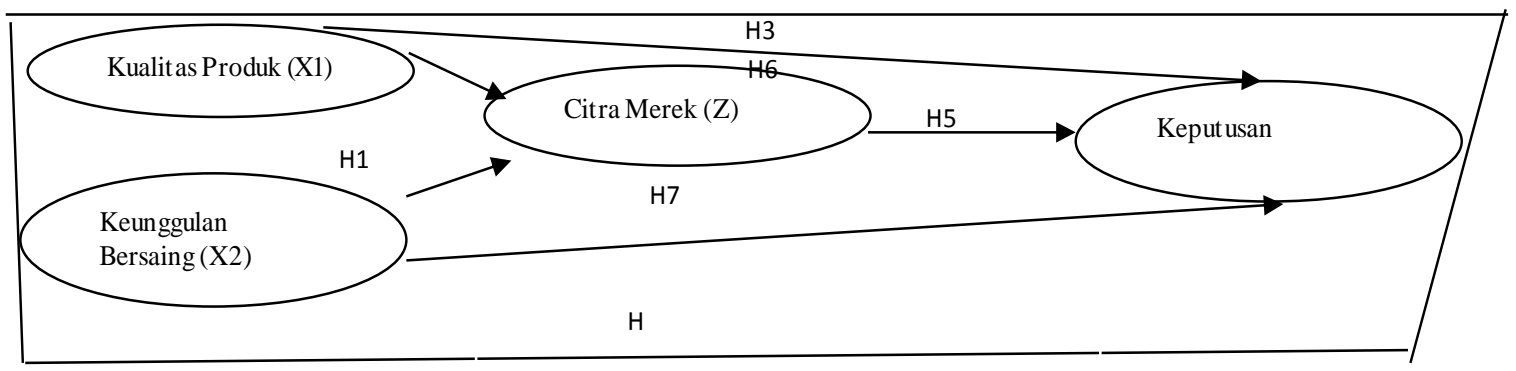

Gambar 4.

Kerangka pemikiran

\section{Metode Riset}

Populasi di dalam penelitian ini adalah mahasiswa Universitas 17 Agustus 1945 Jakarta (UTA'45) yang menggunakan sepeda motor Honda matik berjumlah 198 orang. Penarikan sampel menggunakan rumus slovin yaitu sebesar 132 orang. Responden dalam penelitian ini adalah mahasiswa Universitas 17 Agustus 1945 Jakarta (UTA'45) angkatan tahun 2012 - 2015 yang menggunakan sepeda motor Honda matic. Cara menentukan jumlah sampel dalam penelitian ini menggunakan rumus Slovin dengan estimasi penyimpangan sebesar 5\%. Teknik pengambilan sampelnya dalam penelitian ini menggunakan purposive sampling yaitu dilakukan dengan mengambil orang - orang yang terpilih betul oleh peneliti menurut ciri - ciri khusus yang dimiliki oleh sampel itu (Soeratno dan Arsyad, 2008). Ciri - ciri khusus dalam penelitian ini adalah mahasiswa yang telah menggunakan sepeda motor Honda matic > 2 tahun, mahasiswa reguler pagi yang memiliki keterlibatan dahanya sebagai influencer (memberikan nasihat atau saran kepada orang tua untuk membeli sepeda motor Honda matic) dan mahasiswa reguler malam berperan sebagai influencer (orang yang memberikan nasihat atau saran), decider (orang yang memutuskan pembelian sepeda motor Honda matic) serta buyer (orang yang melakukan pembelian aktual sepeda motor Honda matic).

\section{Operasionalisasi Variabel Dan Pengukuran}

Dalam pokok bahasan ini terdapat satu variabel dependen (terikat) yang merupakan variabel yang dipengaruhi oleh variabel lain yaitu keputusan pembelian (Y), dua variabel independen (bebas) merupakan variabel yang menjadi penyebab timbulnya variabel 
dependen yaitu kualitas produk $\left(\mathrm{X}_{1}\right)$ dan

mempengaruhi hubungan variabel independen

keunggulan bersaing $\left(\mathrm{X}_{2}\right)$, serta satu variabel

dan dependen yaitu citra merek (Z). Masing -

intervening yang secara teori mampu

masing didefinisikan sebagai berikut :

Tabel 4.

Operasionalisasi variable dan pengukuran

\begin{tabular}{|c|c|c|c|}
\hline VARIABEL & DEFINISI VARIABEL & INDIKATOR & SKALA \\
\hline $\begin{array}{l}\text { Keputusan } \\
\text { pembelian (Y) }\end{array}$ & $\begin{array}{l}\text { Keputusan pembelian adalah } \\
\text { adalah suatu tindakan yang } \\
\text { dilakukan konsumen untuk } \\
\text { memutuskan membeli suatu } \\
\text { produk baik berupa barang } \\
\text { maupun jasa yang dipasarkan } \\
\text { sesuai dengan kebutuhan } \\
\text { dan keinginan konsumen itu } \\
\text { sendiri. }\end{array}$ & $\begin{array}{l}\text { 1. Pertimbangan manfaat produk } \\
\text { setelah membeli } \\
\text { 2. Keinginan untuk membeli ulang } \\
\text { 3. Metode pembayaran, dengan cara } \\
\text { pembelian secara tunai maupun kredit } \\
\text { 4. Rekomendasi dari rekan atau } \\
\text { kerabat lainnya } \\
\text { 5. Kemudahan mendapat suku cadang } \\
\text { sepeda motor Honda matic }\end{array}$ & Likert 1-5 \\
\hline Kualitas produk (X1) & \begin{tabular}{|lrr} 
& & \\
& & \\
Kualitas & produk & adalah \\
kemampuan & suatu & produk \\
dalam rangka & memenuhi \\
kebutuhan & dan & keinginan \\
konsumen & sesuai & dengan \\
standar & kualitas & yang \\
berlaku. & &
\end{tabular} & $\begin{array}{l}\text { 6. Efisiensi bahan bakar } \\
\text { 7. Produk tidak mudah rusak dan } \\
\text { memiliki umur ekonomis yang lama } \\
\text { 8. Daya tahan mesin yang tangguh dan } \\
\text { teruji } \\
\text { 9. Bahan baku yang berkualitas ( kuat ) } \\
\text { 10.Desain produk yang mengesankan } \\
\text { dan cocok bagi semua kalangan }\end{array}$ & Likert 1-5 \\
\hline $\begin{array}{l}\text { Keunggulan } \\
\text { bersaing (X2) }\end{array}$ & $\begin{array}{l}\text { Keunggulan bersaing adalah } \\
\text { kemampuan yang dimiliki } \\
\text { oleh perusahaan dalam } \\
\text { menghasilkan suatu produk } \\
\text { atau jasa dengan memberikan } \\
\text { nilai lebih kepada konsumen } \\
\text { sehingga memampukan } \\
\text { perusahaan bersaing secara } \\
\text { efektif dan lebih unggul } \\
\text { dibandingkan rang } \\
\text { lainnya. }\end{array}$ & $\begin{array}{l}\text { 11.Keunikan produk } \\
\text { 12.Harga jual kembali tinggi } \\
\text { 13.Pelayanan purna jual kepada } \\
\text { pelanggan (kualitas pelayanan) } \\
\text { 14.Model sepeda motor Honda matic } \\
\text { yang beragam dan menarik }\end{array}$ & Likert 1-5 \\
\hline Citra merek (Z) & $\begin{array}{l}\text { Citra merek adalah persepsi } \\
\text { dan keyakinan konsumen } \\
\text { terhadap suatu produk } \\
\text { berdasarkan pengalaman } \\
\text { yang telah dirasakan dan } \\
\text { terangkum di dalam ingatan } \\
\text { konsumen. }\end{array}$ & $\begin{array}{l}\text { 15.Merek sudah lama dikenal dan } \\
\text { menjadi merek pelopor pertama untuk } \\
\text { produk sepeda motor } \\
\text { 16.Reputasi merek yang baik } \\
\text { 17.Mampu meningkatkan citra pemakai } \\
\text { 18.Promosi yang dilakukan melalui } \\
\text { iklan } \\
\text { 19.Membandingkan dengan merek lain } \\
\text { sebelum membeli }\end{array}$ & Likert $1-5$ \\
\hline
\end{tabular}




\section{Metode Analisis Data}

Metode analisis data yang dipergunakan di dalam penelitian ini adalah Structural Equation Modeling - Partial Least Square (SEM-PLS) dengan menggunakan software Smart PLS versi 3. Prosedur regresi Partial Least Squares (PLS) digunakan untuk memperkirakan kuadrat terkecil parsial model - model regresi atau disebut proyeksi terhadap struktur laten (Sarwono dan Narimawati 2015). Sebelum uji hipotesis terlebih dahulu dilakukan uji kelayakan data yaitu dengan uji validitas dengan metode outer loading. Selanjutnya uji reliabilitas data dilakukan dengan melakukan pengujian composite reliability. Selanjutnya uji hipotesis dilakukan dengan menggunakan output inner weight dari Partial Least Square.

\section{PEMBAHASAN}

Uji Validitas dengan Outer Loading

\begin{tabular}{|c|c|c|c|c|c|}
\hline & $\begin{array}{c}\text { Original } \\
\text { Sample } \\
(\mathbf{O})\end{array}$ & $\begin{array}{c}\text { Sample } \\
\text { Mean } \\
\text { (M) }\end{array}$ & $\left|\begin{array}{l}\text { Standard } \\
\text { Deviation } \\
\text { (STDEV) }\end{array}\right|$ & T Stat & $\begin{array}{c}P \\
\text { Values }\end{array}$ \\
\hline $\begin{array}{l}\text { Keunggulan } \\
\text { Bersaing * } \\
\text { Keunggulan } \\
\text { Bersaing <- } \\
\text { Quadratic Effect 2 }\end{array}$ & 1.000 & 1.000 & 0.000 & & \\
\hline $\begin{array}{l}\text { Kualitas Produk * } \\
\text { Kualitas Produk < } \\
\text { Quadratic Effect } 1\end{array}$ & 1.000 & 1.000 & 0.000 & & \\
\hline $\begin{array}{l}\text { X1.P1 < - Kualitas } \\
\text { Produk }\end{array}$ & 0.843 & 0.842 & 0.025 & 33.959 & 0.000 \\
\hline $\begin{array}{l}\text { X1.P2<- Kualitas } \\
\text { Produk }\end{array}$ & 0.736 & 0.734 & 0.047 & 15.678 & 0.000 \\
\hline $\begin{array}{l}\text { X1.P3 < - Kualitas } \\
\text { Produk }\end{array}$ & 0.765 & 0.759 & 0.038 & 19.899 & 0.000 \\
\hline $\begin{array}{l}\text { X1.P4 < - Kualitas } \\
\text { Produk }\end{array}$ & 0.717 & 0.716 & 0.044 & 16.215 & 0.000 \\
\hline $\begin{array}{l}\text { X1.P5 < - Kualitas } \\
\text { Produk }\end{array}$ & 0.738 & 0.738 & 0.044 & 16.684 & 0.000 \\
\hline $\begin{array}{l}\text { X2.P1<- } \\
\text { Keunggulan } \\
\text { Bersaing }\end{array}$ & 0.696 & 0.693 & 0.062 & 11.196 & 0.000 \\
\hline $\begin{array}{l}\text { X2.P2<- } \\
\text { Keunggulan } \\
\text { Bersaing } \\
\end{array}$ & 0.655 & 0.645 & 0.071 & 9.208 & 0.000 \\
\hline $\begin{array}{l}\mathrm{X} 2 . \mathrm{P} 3<- \\
\text { Keunggulan } \\
\text { Bersaing }\end{array}$ & 0.701 & 0.700 & 0.064 & 11.029 & 0.000 \\
\hline $\begin{array}{l}\text { X2.P4<- } \\
\text { Keunggulan } \\
\text { Bersaing } \\
\end{array}$ & 0.788 & 0.789 & 0.039 & 20.012 & 0.000 \\
\hline $\begin{array}{l}\text { Y.P1<- } \\
\text { Keputusan } \\
\text { Pembelian }\end{array}$ & 0.798 & 0.796 & 0.035 & 22.871 & 0.000 \\
\hline $\begin{array}{l}\text { Y.P2<- } \\
\text { Keputusan } \\
\text { Pembelian }\end{array}$ & 0.755 & 0.753 & 0.040 & 19.077 & 0.000 \\
\hline $\begin{array}{l}\text { Y.P3<- } \\
\text { Keputusan } \\
\text { Pembelian }\end{array}$ & 0.781 & 0.780 & 0.037 & 21.014 & 0.000 \\
\hline $\begin{array}{l}\text { Y.P4<- } \\
\text { Keputusan } \\
\text { Pembelian }\end{array}$ & 0.721 & 0.723 & 0.046 & 15.750 & 0.000 \\
\hline $\begin{array}{l}\text { Y.P5<- } \\
\text { Keputusan } \\
\text { Pembelian }\end{array}$ & 0.786 & 0.784 & 0.040 & 19.548 & 0.000 \\
\hline $\begin{array}{l}\text { Z.P1<- Citra } \\
\text { Merek }\end{array}$ & 0.706 & 0.707 & 0.048 & 14.733 & 0.000 \\
\hline $\begin{array}{l}\text { Z.P2<- Citra } \\
\text { Merek }\end{array}$ & 0.803 & 0.804 & 0.030 & 26.607 & 0.000 \\
\hline $\begin{array}{l}\text { Z.P3<- Citra } \\
\text { Merek }\end{array}$ & 0.759 & 0.755 & 0.043 & 17.495 & 0.000 \\
\hline $\begin{array}{l}\text { Z.P4<- Citra } \\
\text { Merek }\end{array}$ & 0.753 & 0.754 & 0.039 & 19.194 & 0.000 \\
\hline $\begin{array}{l}\text { Z.P5 <- Citra } \\
\text { Merek }\end{array}$ & 0.750 & 0.750 & 0.041 & 18.250 & 0.000 \\
\hline
\end{tabular}


Kuesioner dapat dikatakan valid apabila pertanyaan di dalam kuesioner mampu mengemukakan sesuatu yang nantinya di ukur oleh kuesioner. Uji validitas dilakukan dengan analisa faktor yang dimaksudkan untuk memastikan bahwa masing - masing pertanyaan akan terklasifikasi pada variabel yang telah ditentukan. Outer loadings atau validitas konvergen digunakan untuk menguji unidimensionalitas dari masing-masing konstruk Chin (1998). Nilai indikator faktor yang lebih besar atau sama dengan 0,5 dapat dikatakan valid. Hasil tabel di atas pada Outer Loadings p value (Original Sample) di atas 0,5 dan T Statisticsnya lebih dari 1,96 maka pada uji validitas diatas semua indikator dinyatakan valid.

\section{Uji Reliabilitas dengan Composite}

Reliability

Uji keandalan data ini dilakukan dengan uji composite reliability. Chin W (1998) mengatakan bahwa " the unidimensionlity of the block of variables may be assessed by using composite reliability (should be > 0,7)". Data yang memiliki composite reliability > 0,7 memiliki reliabilitas yang tinggi.
Composite Reliability

\begin{tabular}{|l|l|l|l|l|l|}
\hline & $\begin{array}{c}\text { Original } \\
\text { Sample } \\
(\mathbf{O})\end{array}$ & $\begin{array}{c}\text { Sample } \\
\text { Mean } \\
(\mathbf{M})\end{array}$ & $\begin{array}{c}\text { Standard } \\
\text { Deviation } \\
\text { (STDEV) }\end{array}$ & T Stat & $\begin{array}{c}\text { P } \\
\text { Values }\end{array}$ \\
\hline $\begin{array}{l}\text { Citra } \\
\text { Merek }\end{array}$ & 0.869 & 0.868 & 0.015 & 58.594 & 0.000 \\
\hline $\begin{array}{l}\text { Keputusan } \\
\text { Pembelian }\end{array}$ & 0.878 & 0.877 & 0.013 & 66.291 & 0.000 \\
\hline $\begin{array}{l}\text { Keunggula } \\
\text { n Bersaing }\end{array}$ & 0.804 & 0.801 & 0.028 & 29.019 & 0.000 \\
\hline $\begin{array}{l}\text { Kualitas } \\
\text { Produk }\end{array}$ & 0.873 & 0.871 & 0.015 & 59.827 & 0.000 \\
\hline $\begin{array}{l}\text { Quadratic } \\
\text { Effect 1 }\end{array}$ & 1.000 & 1.000 & 0.000 & & \\
\hline $\begin{array}{l}\text { Quadratic } \\
\text { Effect 2 }\end{array}$ & 1.000 & 1.000 & 0.000 & & \\
\hline
\end{tabular}

Tabel pada composite realibility diatas menunjukkan data diatas $>0,7$ karena semua variabel di atas nilainya lebih dari 0,7 . Dengan demikian maka dapat disimpulkan bahwa data kualitas produk (X1), data keunggulan bersaing (X2), data citra merek (Z) serta data keputusan pembelian (Y) adalah reliable dan dapat dipergunakan untuk uji hipotesis.

\section{Cronbach's Alpha}

\begin{tabular}{|l|l|l|l|l|l|}
\hline & $\begin{array}{c}\text { Original } \\
\text { Sample } \\
(\mathbf{O})\end{array}$ & $\begin{array}{c}\text { Sample } \\
\text { Mean } \\
(\mathbf{M})\end{array}$ & $\begin{array}{c}\text { Standard } \\
\text { Deviation } \\
(\mathbf{S T D E V})\end{array}$ & T Stat & $\begin{array}{c}\mathbf{P} \\
\text { Values }\end{array}$ \\
\hline Citra Merek & 0.811 & 0.811 & 0.024 & 33.153 & 0.000 \\
\hline $\begin{array}{l}\text { Keputusan } \\
\text { Pembelian }\end{array}$ & 0.826 & 0.825 & 0.022 & 38.210 & 0.000 \\
\hline $\begin{array}{l}\text { Keunggulan } \\
\text { Bersaing }\end{array}$ & 0.675 & 0.668 & 0.058 & 11.599 & 0.000 \\
\hline $\begin{array}{l}\text { Kualitas } \\
\text { Produk }\end{array}$ & 0.818 & 0.815 & 0.024 & 34.163 & 0.000 \\
\hline $\begin{array}{l}\text { Quadratic } \\
\text { Effect 1 }\end{array}$ & 1.000 & 1.000 & & & \\
\hline $\begin{array}{l}\text { Quadratic } \\
\text { Effect 2 }\end{array}$ & 1.000 & 1.000 & & & \\
\hline
\end{tabular}


Apabila cronbach's alpha diatas 0,5 maka dinyatakan valid dan sebaliknya apabila cronbach's alpha dibawah 0,5 maka dinyatakan tidak valid. Berdasarkan data yang diuji diatas, pada cronbach's alpha pada masing - masing variabel berada di atas nilainya lebih dari 0,5 dan dinyatakan valid. Nilai terendah pada variabel di atas adalah sebesar 0.675 pada variabel keunggulan bersaing.

\section{Pengujian Hipotesis}

Pengujian hipotesis dalam penelitian ini menggunakan inner weights ( structural model ) yang diolah dengan PLS. Berikut merupakan hasil pembuktian hipotesis yang diperoleh dari model penelitian serta hasil pengujian hipotesis penelitiannya dapat dilihat pada gambar berikut ini :

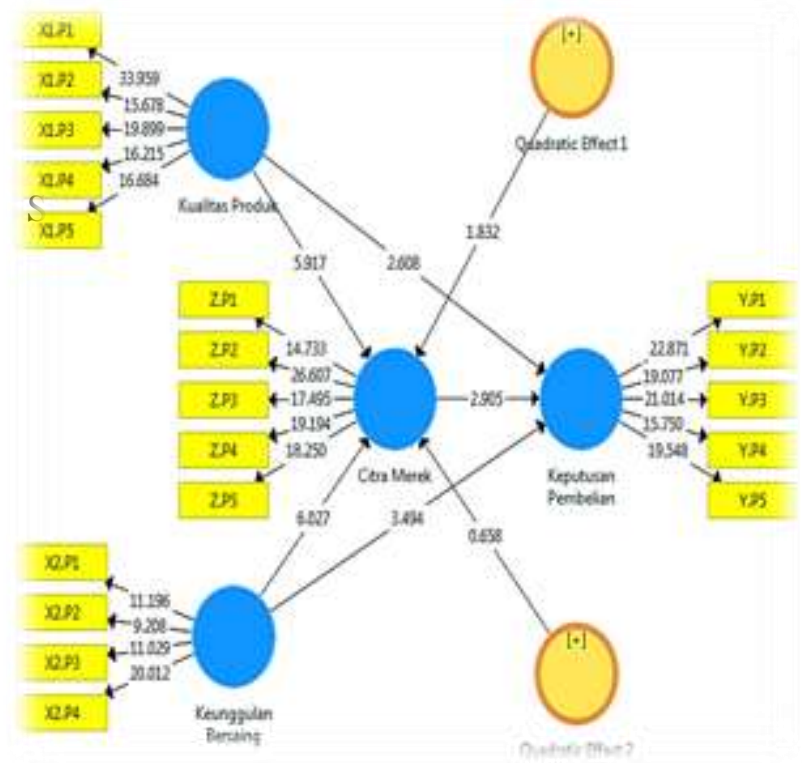

Gambar 2.

Model structural PLS Bootstrapping

\section{Pembuktian Hipotesis Pertama}

$\mathrm{H}_{1}=$ Kualitas produk berpengaruh positif signifikan terhadap citra merek. Hal ini dibuktikan dari hasil yang menunjukkan bahwa nilai original sample $=0.451, \mathrm{~T}$ Statistics $=5.917>1.96$ dan $\mathrm{P}$ Values $=0.000$ $<0.05$. Artinya bahwa kualitas produk berpengaruh positif signifikan. Dengan demikian $\mathrm{H}_{1}$ dalam penelitian ini diterima. Hasil penelitian ini konsisten dengan penelitian terdahulu yaitu penelitian (Anis dkk, 2015; Yusmawan et al, 2014; Noerchoidah, 2013) yang menyatakan kualitas produk mempunyai pengaruh positif signifikan terhadap citra merek. Menurut penelitian ini, banyak responden yang menyatakan bahwa sepeda motor Honda matic menggunakan bahan baku berstandar Internasional yang sudah teruji kualitasnya sehingga mampu menciptakan reputasi merek yang baik dan handal dibenak konsumen.

\section{Pembuktian Hipotesis Kedua}

$\mathrm{H}_{2}=$ Berdasarkan tabel XVII di atas menunjukkan bahwa nilai original sample $=$ 0.450, T Statistics $=6.027>1.96$ dan P Values $=0.000<0.05$. Dengan demikian $\mathrm{H}_{2}$ dalam penelitian ini yang menyatakan bahwa pengaruh keunggulan bersaing positif 
signifikan terhadap citra merek diterima. Hasil

penelitian ini konsisten dengan penelitian terdahulu (Lubis, 2012; Erlangga dan Sisilia, 2014; Ratnawati, 2013) yang mengatakan bahwa keunggulan bersaing berpengaruh positif signifikan terhadap citra merek. Menurut penelitian ini, banyaknya responden yang menyatakan bahwa sepeda motor Honda matic memiliki keunggulan dengan memberikan kualitas pelayanan purna jual kepada pelanggan setelah melakukan pembelian dengan memberikan service excellent.

\section{Pembuktian Hipotesis Ketiga}

$\mathrm{H}_{3}=$ Berdasarkan tabel XVII di atas menunjukkan bahwa nilai original sample $=$ 0.235 , T Statistics $=2.608>1.96$ dan P Values $=0.009<0.05$. Dengan demikian $\mathrm{H}_{3}$ dalam penelitian ini menyatakan bahwa pengaruh kualitas produk mempengaruhi secara positif signifikan terhadap keputusan pembelian diterima. Hasil penelitian ini konsisten dengan penelitian terdahulu yaitu penelitian (Puspita dkk, 2016; Hasan, 2015; Purwati, 2012) bahwa kualitas produk mempengaruhi secara positif signifikan terhadap keputusan pembelian. Menurut penelitian ini, banyaknya responden yang menyatakan bahwa sepeda motor Honda matic memiliki mesin yang tangguh dan berstandar Internasional serta efisiensi dalam penggunaan bahan bakar minyak sehingga sepeda motor Honda matic dapat dipakai dalam jangka waktu yang lama.

\section{Pembuktian Hipotesis Keempat}

$\mathrm{H}_{4}=$ Berdasarkan tabel XVII di atas menunjukkan bahwa nilai original sample $=$ 0.323 , T Statistics $=3.494>1.96$ dan P Values $=0.001<0.05$. Dengan demikian bahwa hubungan antara keunggulan bersaing dengan keputusan pembelian adalah positif signifikan. Dengan demikian $\mathrm{H}_{4}$ dalam penelitian ini menyatakan bahwa keunggulan bersaing mempengaruhi secara positif signifikan terhadap keputusan pembelian diterima. Hasil penelitian ini konsisten dengan penelitian terdahulu yaitu penelitian (Diyah, 2013; Saputra dkk, 2015; Mahmud, 2014) bahwa keunggulan bersaing mempengaruhi secara positif signifikan terhadap keputusan pembelian. Menurut penelitian ini, banyaknya responden yang menyatakan bahwa Honda memberikan kemudahan bagi konsumen mendapatkan spare part Honda dan bengkel resmi (AHASS) untuk memberikan service kepada konsumen menjadi salah satu keunggulan yang dimiliki Honda. 


\section{Pembuktian Hipotesis Kelima}

$\mathrm{H}_{5}=$ Berdasarkan tabel XVII di atas menunjukkan bahwa nilai original sample $=$ 0.294, T Statistics $=2.905>1.96$ dan P Values $=0.004<0.05$. Dengan demikian bahwa hubungan antara citra merek terhadap keputusan pembelian adalah positif signifikan. Maka $\mathrm{H}_{5}$ dalam penelitian ini adalah bahwa citra merek mempengaruhi secara positif signifikan terhadap keputusan pembelian diterima. Hasil penelitian ini konsisten dengan penelitian terdahulu yaitu penelitian (Darmayanti dan Jatra, 2016; Ristiawan dan Farida, 2015; Listyawati, 2014) bahwa citra merek mempengaruhi secara positif signifikan terhadap keputusan pembelian. Menurut penelitian ini, banyaknya responden yang menyatakan bahwa sepeda motor Honda matic memiliki reputasi merek yang handal dan baik serta menjadi pelopor sepeda motor pertama di Indonesia sehingga responden merasa tertarik untuk membeli sepeda motor Honda khususnya matic.

\section{Pembuktian Hipotesis Keenam}

$\mathrm{H}_{6}=$ Kualitas produk mampu mempengaruhi secara positif tidak signifikan terhadap keputusan pembelian melalui citra merek. Hal ini dibuktikan dari hasil yang menunjukkan bahwa nilai original sample $=$ 0.109, T Statistics $=1.832<1.96$ dan P Values $=0.068>0.05$. Dengan demikian $\mathrm{H}_{6}$ dalam penelitian ini menunjukkan bahwa citra merek tidak mampu memediasi secara positif signifikan dengan kualitas produk terhadap keputusan pembelian dan hipotesis ditolak. Nilai yang tidak signifikan ini menunjukkan bahwa kualitas produk yang diberikan Honda belum tentu dapat membentuk citra merek yang positif di benak konsumen. Meskipun merek Honda sudah lama dikenal dan menjadi merek pelopor pertama untuk produk sepeda motor, namun citra merek tidak mampu mempengaruhi hubungan kualitas produk terhadap keputusan pembelian. Berdasarkan penelitian yang telah dilakukan, beberapa responden menyatakan bahwa meskipun sepeda motor Honda matic sudah lama dikenal namun sepeda motor Honda matic memiliki desain sepeda motor yang terbatas dan tidak mengikuti perkembangan jaman (monoton). Sepeda motor Honda matic tidak banyak mengalami perubahan yang signifikan terhadap desain (model) sepeda motornya sehingga mahasiswa kurang tertarik dengan model tersebut. Hal ini tidak sesuai dengan penelitian sebelumnya (Wahid, 2014). 


\section{Pembuktian Hipotesis Ketujuh}

$$
\mathrm{H}_{7}=\text { Keunggulan bersaing mampu }
$$

mempengaruhi secara positif tidak signifikan terhadap keputusan pembelian melalui citra merek. Hal ini dibuktikan dari hasil yang menunjukkan bahwa nilai original sample $=$ $0.034, \mathrm{~T}$ Statistics $=0.658<1.96$ dan $\mathrm{P}$ Values $=0.511>0.05$. Dengan demikian $\mathrm{H}_{7}$ dalam penelitian ini menunjukkan bahwa citra merek tidak mampu memediasi secara positif signifikan dengan keunggulan bersaing terhadap keputusan pembelian dan hipotesis ditolak. Hal ini disebabkan karena meskipun merek Honda sudah akrab di benak konsumen dan menjadi merek pelopor pertama untuk produk sepeda motor, namun citra merek tidak mampu mempengaruhi hubungan keunggulan bersaing terhadap keputusan pembelian. Berdasarkan penelitian yang telah dilakukan, beberapa responden menyatakan bahwa sepeda motor Honda matic memiliki harga jual spare part yang lebih mahal dibandingkan harga spare part motor matic merek lainnya sehingga mahasiswa kurang tertarik untuk menggunakan sepeda motor Honda matic dikarenakan biaya perawatan yang cukup mahal. Hal ini tidak sesuai dengan penelitian sebelumnya (Diyah dkk, 2013), (Ratnawati, 2013) dan (Sari, 2013).

\section{KESIMPULAN, IMPLIKASI DAN KETERBATASAN}

Sesuai dengan analisis data yang telah dilakukan ditarik kesimpulan antara lain sebagai berikut:

a. Hasil pengujian hipotesis pertama ditemukan bahwa kualitas produk mempengaruhi secara positif signifikan terhadap citra merek sepeda motor Honda matic. Hasil penelitian ini diterima atau mendukung hipotesis pertama. Berdasarkan hasil penelitian tersebut diketahui banyaknya responden yang menyatakan bahwa sepeda motor Honda matic menggunakan bahan baku berstandar Internasional yang sudah teruji kualitasnya sehingga mampu menciptakan reputasi merek yang baik dan handal dibenak konsumen.

b. Hasil pengujian hipotesis kedua bahwa keunggulan bersaing mempengaruhi secara positif signifikan terhadap citra merek. Hasil penelitian ini diterima atau mendukung hipotesis kedua. Berdasarkan hasil penelitian tersebut diketahui banyaknya responden yang menyatakan 
bahwa sepeda motor Honda matic memiliki keunggulan dengan memberikan kualitas pelayanan purna jual kepada pelanggan setelah melakukan pembelian dengan memberikan service excellent. Hal ini berarti bahwa keunggulan bersaing mampu menciptakan dan menambah citra merek yang ada pada produk tersebut.

c. Hasil pengujian hipotesis ketiga bahwa kualitas produk mampu memberi pengaruh positif signifikan terhadap keputusan pembelian. Hasil penelitian ini diterima atau mendukung hipotesis ketiga. Berdasarkan hasil penelitian tersebut diketahui banyaknya responden yang menyatakan bahwa sepeda motor Honda matic memiliki mesin yang tangguh dan berstandar Internasional serta efisiensi dalam penggunaan bahan bakar minyak sehingga sepeda motor Honda matic dapat dipakai dalam jangka waktu yang lama.

d. Hasil pengujian hipotesis keempat bahwa keunggulan bersaing memiliki pengaruh positif signifikan terhadap keputusan pembelian. Hasil penelitian ini diterima atau mendukung hipotesis keempat. Berdasarkan hasil penelitian tersebut diketahui banyaknya responden yang menyatakan bahwa sepeda motor Honda matic memiliki harga jual kembali yang lebih tinggi atau relatif tinggi dibandingkan harga jual merek sepeda motor matic lainnya.

e. Hasil pengujian hipotesis kelima bahwa citra merek memiliki pengaruh positif signifikan terhadap keputusan pembelian. Hasil penelitian ini diterima atau mendukung hipotesis kelima. Citra merek mampu mempengaruhi perilaku konsumen dan kepercayaan konsumen terhadap produk yang ditawarkan sehingga mampu mempengaruhi keputusan pembelian konsumen. Berdasarkan hasil penelitian tersebut diketahui banyaknya responden yang menyatakan bahwa sepeda motor Honda matic memiliki reputasi merek yang handal dan baik serta menjadi pelopor sepeda motor pertama di Indonesia sehingga responden merasa tertarik untuk membeli sepeda motor Honda khususnya matic.

f. Hasil pengujian hipotesis keenam bahwa citra merek tidak mampu memediasi secara positif signifikan kualitas produk terhadap keputusan pembelian. Hal ini berarti hipotesis keenam ditolak. Hal ini berarti 
bahwa citra merek tidak sejalan dengan kualitas produk terhadap keputusan pembelian. Citra merek yang baik belum pasti mencerminkan kualitas produk itu sendiri dan mampu mendorong konsumen untuk membeli produk tersebut.

g. Hasil pengujian hipotesis ketujuh bahwa citra merek tidak mampu memediasi secara positif signifikan keunggulan bersaing terhadap keputusan pembelian. Hal ini berarti hipotesis ketujuh ditolak. Hal ini berarti bahwa citra merek tidak sejalan dengan keunggulan bersaing terhadap keputusan pembelian.

\section{Keterbatasan Penelitian}

Penelitian ini dilakukan berdasarkan kuesioner sebagai teknik pengumpulan data yang disebarkan kepada mahasiswa pengguna sepeda motor Honda matic di Universitas 17 Agustus 1945 Jakarta (UTA’45). Hal ini dapat memungkinkan bahwa data yang dihasilkan menjadi bias karena adanya perbedaan persepsi antara peneliti dan responden terhadap pertanyaan - pertanyaan yang diajukan. 


\section{DAFTAR PUSTAKA}

Anis L.M., Suharyono, Sunarti, 2015, "Pengaruh Kualitas Produk Terhadap International Brand Image Serta Dampaknya Terhadap Keputusan Pembelian Mahasiswa Pembeli Dan Pengguna Laptop Lenovo Di Fakultas Ilmu Administrasi Universitas Brawijaya", Jurnal Administrasi Bisnis, Vol. 28, No. 2, Malang: Universitas Brawijaya Malang.

Darmayanti dan Jatra, 2016, "Pengaruh Atribut Produk Dan Citra Merek Terhadap Keputusan Pembelian Smartphone Samsung Android Di Kabupaten Gianyar", Fakultas Ekonomi dan Bisnis, Bali: Universitas Udayana Bali.

Diyah, Zainul dan Yaningwati, 2013, "Pengaruh Pelayanan Purna Jual Terhadap Keputusan Pembelian (Survei Pada Masyarakat Kecamatan Pronojiwo Kabupaten Lumajang yang Menggunakan Honda Beat Plat N Lumajang Produksi 2010 - 2012)", Fakultas Ilmu Administrasi.

Edi, Sarwo, 2013, "Skripsi Pengaruh Citra Merek, Sikap Konsumen Dan Asosiasi Merek Terhadap Proses Keputusan Pembelian Konsumen (Studi Empiris Pertimbangan Mahasiswa UNNES Dalam Pembelian Laptop Toshiba)", Universitas Negeri Semarang.

Erlangga dan Sisilia, 2014, "Pengaruh Kualitas Pelayanan Terhadap Brand Image (Studi Pada Hotel Nusantara Di Bandar Lampung)", Fakultas Komunikasi dan Bisnis, Universitas Telkom.

Ferrinadewi, Erna, 2008, Merek dan Psikologi Konsumen, Yogyakarta: Graha Ilmu.

Ghanimata dan Kamal, 2012, "Analisis Pengaruh Harga, Kualitas Produk, Dan Lokasi Terhadap Keputusan Pembelian Studi pada Pembeli Produk Bandeng Juwana Elrina Semarang)", Diponegoro Journal of Management, Vol. 1. No. 2, Semarang: Badan Penerbit Universitas Diponegoro.

Ginting, Nembah, 2012, Manajemen Pemasaran, Cetakan 2, Bandung: Yrama Widya.

Gu, Mingya, 2013, “The Impact Of Visual Appearance On Brand Image”, Degree Thesis International Business, Arcada.

Hasan D.K., 2015, "Pengaruh Kualitas Produk dan Merek terhadap Keputusan Pembelian Smartphone Merek Iphone pada Mahasiswa Ilmu Administrasi Niaga / Bisnis FISIP USU”, Fakultas Ilmu Sosial dan Ilmu Politik, Universitas Sumatera Utara.

Jatmiko R.D., 2004, Manajemen Strategi, Edisi Pertama, Jakarta: Salemba Empat.

Kotler, Philip, 2010, Prinsip-Prinsip Pemasaran, Jakarta: Erlangga.

Kotler, Philip dan Amstrong, Gary, 2012, Principles of Marketing, New Jersey: Prentice Hall.

Kotler, Philip dan Amstrong, Gary, 2008, Prinsip - Prinsip Pemasaran Jilid 1, Edisi Keduabelas, Jakarta: PT. Penerbit Erlangga.

Kotler, Philip dan Amstrong, Gary, 2007, Dasar-Dasar Pemasaran, Edisi Kesembilan, Alih Bahasa: Alexander Sindoro, Jakarta: PT. Indeks Kelompok Gramedia.

Kotler, Philip dan Amstrong, Gary, 2006, Prinsip - Prinsip Pemasaran, Edisi Kedua belas, Jakarta: PT. Penerbit Erlangga.

Kotler, Philip dan Amstrong, Gary, 2005, Manajemen Pemasaran, Edisi Kesebelas, Jakarta: PT. Indeks Kelompok Gramedia.

Kotler, Philip dan Keller, 2012, Marketing Management, $14^{\text {th }}$ Edition, New Jersey: Pretince Hall.

Kotler, Philip dan Keller, 2012, Marketing Management 13, New Jersey: Pearson Pretince Hall, Inc.

Listyawati I.H., 2014, "Analisis Pengaruh Citra Merek Terhadap Keputusan Pembelian Kartu Simpati Di Yogyakarta", JBMA, Vol. 2, No. 1, Yogyakarta: Akademi Manajemen Administrasi YPK Yogyakarta.

Lubis, 2012, "Analisis Pengaruh Kualitas Pelayanan Terhadap Citra Merek Pada Poliklinik RS. Haji Medan", Fakultas Ekonomi, Universitas Sumatera Utara.

Mahmud, 2014, "Pengaruh Desain Produk Dan Layanan Purna Jual Terhadap Keputusan Konsumen Membeli Sepeda Motor Yamaha Merek New V-Ixion FI (Full Injection)", Jurnal Sketsa Bisnis, Vol. 1.

Noerchoidah, 2013, "Analisis Pengaruh Harga, Kualitas Produk Dan Iklan Terhadap Brand Image Dan Keputusan Pembelian Sepeda Motor Merek Kawasaki”, Jurnal WIG, Vol. 3, No. 1.

Priyanto, Rosa, dan Syarif, Rini, 2014, "Pengaruh Personal Selling dan Kualitas Produk terhadap Keputusan Pembelian”, Jurnal Ilmiah Manajemen Kesatuan (JIMKES), Vol. 2, No. 1, Bogor: Sekolah Tinggi Ilmu Ekonomi Kesatuan Bogor. 
Purba, J.R., 2011, "Skripsi Pengaruh Keunggulan Bersaing Dalam Perumusan Strategi Pemasaran Terhadap Citra Merek Pada Rumah Makan Wong Solo Medan”, Universitas Sumatera Utara, Medan.

Purwati, Setiawan, dan Rohmawati, 2012, "Pengaruh Harga Dan Kualitas Produk Terhadap Keputusan Pembelian Motor Honda Matic Beat (Studi Kasus Pada PT. Nusantara Solar Sakti)", Jurnal Ekonomi dan Informasi Akuntansi (JENIUS), Vol. 2, No. 3, Politeknik Negeri Sriwijaya.

Puspita, Yulianto, Edy, dan Sunarti, 2016, "Pengaruh Kualitas Produk dan Word Of Mouth terhadap Keputusan Pembelian (Survei Kepada Konsumen Charles \& Keith di Tunjungan Plaza Surabaya)", Jurnal Administrasi Bisnis (JAB), Vol. 34, No. 1, Malang: Universitas Brawijaya Malang.

Ratnawati, Atik, 2013, "Pengaruh Kualitas Layanan Terhadap Brand Image Pada Pasien Rumah Sakit Ortopedi (RSO) Prof.Dr. Soeharso Surakarta Tahun 2012", Jurnal Pendidikan Bisnis dan Ekonomi (BISE), Vol. 1, No. 1, Universitas 11 Maret.

Ristiawan dan Farida, 2015, "Pengaruh Citra Merek (Brand Image) Terhadap Pengambilan Keputusan Pembelian Sepeda Motor Suzuki Satria FU 150 CC Di Kota Pekanbaru (Studi Kasus Pada Konsumen PT. Riau Jaya Cemerlang)", JOM FISIP, Vol. 2, No. 2, Universitas Riau.

Saidani, Rachman M.A., dan Rizan, 2013, "Pengaruh Kualitas Produk Dan Desain Produk Terhadap Keputusan Pembelian Sepatu Olahraga Futsal Adidas Di Wilayah Jakarta Timur", Jurnal Riset Manajemen Sains Indonesia (JRMSI), Vol. 4, No. 2, Universitas Negeri Jakarta.

Sampurno, 2010, Manajemen Stratejik : Menciptakan Keunggulan Bersaing yang Berkelanjutan, Yogyakarta: Gadjah Mada University Press.

Saputra, Sasongko, dan Budiharjo, Agus, 2015, "Pengaruh Inovasi Produk Dan Promosi Terhadap Keputusan Pembelian Pada Distro Klanrock House Concept Store Di Jember”, Fakultas Ilmu Sosial dan Ilmu Politik, Universitas Jember (UNEJ).

Saputra dan Saputro A.F., 2015, Strategi PT Astra Honda Motor dalam mencapai Keunggulan Kompetitif, Manajemen Strategik PT Astra Honda Motor menghadapi persaingan industri sepeda motor di Indonesia, Universitas Negeri Semarang.

Sari, 2013, "Pengaruh Citra Merek Dan Keluarga Terhadap Keputusan Pembelian Honda Beat", Jurnal Ilmu Manajemen, Vol. 1, No. 1, Surabaya: Universitas Negeri Surabaya.

Shintia D.R., 2012, Pengaruh Inovasi Produk Dan Kualitas Produk Terhadap Keunggulan Bersaing Pengusaha Batik Trusmi Di Kabupaten Cirebon, Universitas Pendidikan Indonesia.

Suharno, 2010, Marketing in Practice, Edisi Pertama, Yogyakarta: Graha Ilmu.

Sumarwan, 2008, Perilaku Konsumen: Teori dan Penerapannya dalam Pemasaran. Bogor Selatan: Ghalia Indonesia.

Sunyoto, Danang, 2013, Perilaku Konsumen, Yogyakarta: CAPS (Center for Academic Publishing Service)

Swastha, Handoko, 2011, Manajemen Pemasaran-Analisis Perilaku Konsumen, Yogyakarta: BPFE.

Tambunan, Krystia dan Widiyanto, 2012, "Analisis Pengaruh Citra Merek, Persepsi Kualitas, Dan Harga Terhadap Keputusan Pembelian Bandeng Presto (Studi Kasus pada Konsumen di Bandeng Presto Semarang)", Jurnal Manajemen, Vol. 1. No. 2.

Tjiptono, Fandy, 2008, Strategi Pemasaran, Edisi Ketiga, Yogyakarta: Andi Offset.

Wahid, 2014, "Analisis Pengaruh Kualitas Produk Terhadap Keputusan Pembelian Melalui Citra Merek Dan Nilai Pelanggan", Universitas Diponegoro.

Yusmawan, Suharyono, Kumadji, dan Rahardjo, 2014, "Journal Of The Effect Of The Product Quality Mediation And Brand Image On The Influence Of Pricing Policy And Service Quality Towards Trust”, Journal Of Contemporary Research In Business, Vol. 5, No. 9, Malang: Universitas Brawijaya Malang.

Yusup, Muhammad, 2011, "Skripsi Analisis Pengaruh Promosi, Harga, Kualitas Produk Dan Layanan Purna Jual Terhadap Keputusan Pembelian Sepeda Motor Honda (Studi Kasus pada Mahasiswa Fakultas Ekonomi Universitas Diponegoro Semarang). 